\title{
Small Intestine Cancer Pathologic Distant Metastasis TNM Finding v8
}

National Cancer Institute

\section{Source}

National Cancer Institute. Small Intestine Cancer Pathologic Distant Metastasis TNM

Finding v8. NCI Thesaurus. Code C133831.

A pathologic finding about one or more characteristics of small intestine cancer,

following the rules of the TNM AJCC V8 classification system as they pertain to distant metastases. 